
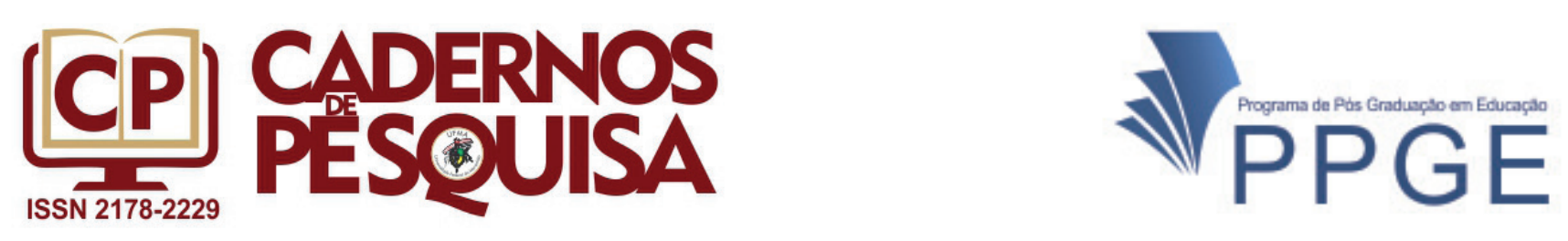

\title{
A Base Nacional Comum Curricular e educação no/do campo: uma relação de (in)consistência
}

\author{
The national curricular common base and education in/of the \\ field: a relationship of (in) consistency
}

\section{La base nacional común curricular y educación en el campo: una relación de (in) consistencia}

\author{
Raimunda Aurea Dias de Sousa \\ (iD) $h t t p: / /$ orcid.org/0000-0002-4646-4500 \\ Alberto Filho Coelho Amorim \\ (iD) http://orcid.org/0000-0002-4646-4500
}

\begin{abstract}
Resumo: No presente trabalho, teve-se como ponto de partida a Base Nacional Comum Curricular supostamente aprovada no Brasil para o Ensino Fundamental em 2017 e Ensino Médio em 2018 na sua (in) consistência com a educação do/no campo. Assim, tem como objetivo compreender a relação de (in)consistência entre a BNCC e a educação no/do campo no que se refere a realidade vivenciada pelos camponeses como condição fundamental para sua existência. A referida pesquisa foi desenvolvida com estudantes e professores da escola Estadual Malaquias Mendes da Silva, localizada no Distrito de Rajada - Petrolina-PE, pautando-se na análise quantitativa/qualitativa dos dados coletados. Com os resultados, ficou perceptível que uma Base Nacional Comum, sendo a mesma criada para guiar o ensino em todo o país, as oportunidades de aprendizagem, como propagandeadas nos meios de comunicação, não serão a mesma, uma vez que o campo tem especificidades que os diferenciam da cidade.
\end{abstract}

Palavras-chave: BNCC. Educação do/no Campo. Terra. Camponês.

\begin{abstract}
In the present work, it had as starting point the National Curricular Common Base (Base Nacional Curricular Comum - BNCC) supposedly approved in Brazil for Elementary School, in 2017, and Secondary School, in 2018, in its (in) consistency with the education in/of the field. Thus, it aims to understand the (in) consistency relationship between BNCC and education in/of the field in what it refers to reality experienced by peasants as a fundamental condition for their existence. This research was developed with students and teachers of the state school Malaquias Mendes da Silva, located in the District of Rajada - Petrolina - PE, based on the quantitative / qualitative analysis of the data collected. With the results, it became clear that the National Curricular Common Base, being created to guide education throughout the country, the learning opportunities, as advertising in the media, will not be the same, since the field has specifics that differentiate them from the city.
\end{abstract}


Keywords: BNCC. Education in/of the Field. Earth. Peasant.

Resumen: En el presente trabajo, se tuvo como punto de partida la Base Nacional Común Curricular supuestamente aprobada en Brasil para la Enseñanza Fundamental, en 2017 y Enseñanza Media, en 2018 en su (in) consistencia con la educación del / en el campo. Así, tiene como objetivo comprender la relación de (in) consistencia entre la BNCC y la educación en el campo en el que se refiere a la realidad vivida por los campesinos como condición fundamental para su existencia. La investigación fue desarrollada con estudiantes y profesores de la escuela estatal Malaquias Mendes da Silva, ubicada en el Distrito de Rajada - Petrolina-PE, pautándose en el análisis cuantitativo / cualitativo de los datos recolectados. Con los resultados, se percibió que una Base Nacional Común, siendo la misma creada para guiar la enseñanza en todo el país, las oportunidades de aprendizaje, como propagandas en los medios de comunicación, no serán la misma, una vez que el campo tiene especificidades que los diferencian de la ciudad.

Palabras clave: BNCC. Educación del / en el Campo. Tierra. Campesino.

\section{INTRODUÇÃO}

Ao se apresentar uma Base Nacional Comum Curricular (BNCC) para a Educação Básica em todos os espaços, sejam eles cidade ou campo julga-se que em ambos, direitos e aprendizagem imediatamente serão consolidados no instante em que a Base foi aprovada pelo Conselho Nacional de Educação em 2017 e 2018.

A Base é uma proposta de atualização dos Parâmetros Curriculares Nacionais (PCNs), publicados em 1997 sendo que as discussões para sua construção estão associadas à LDB 9394/1996, e foram retomadas em 2010, na Conferência Nacional de Educação (CONAE). Em 2014, é publicada a Lei 13.005/2014, que institui o Plano Nacional de Educação (PNE), com vigência de 10 anos, e onde se incluíram quatro metas que tratavam especificamente da construção da base.

No contexto das implicações da imposição de uma Base, especialmente, para educação no/do campo, o ponto de partida para essa investigação ocorreu na escola Estadual Malaquias Mendes da Silva, no povoado de Atalho e na extensão localizada no distrito de Rajada; ambas as distâncias têm aproximadamente $80 \mathrm{~km}$ do Município de Petrolina no sertão de Pernambuco. A motivação que impulsionou a escolha pela escola partiu de observações realizadas no ensino cuja finalidade distancia da realidade do campo e dos filhos de camponeses presentes na escola.

Para Caldeira \& Zaidan (2013):

Ao considerar a atividade docente como expressão do saber pedagógico e este como, ao mesmo tempo, fundamento e produto da atividade docente que acontece no contexto escolar, numa instituição social e historicamente construída, a ação docente é compreendida como uma prática social. Prática que se constrói no cotidiano dos sujeitos nela envolvidos e que, portanto, nela se constituem como seres humanos. (p.19) 
Desse modo, partiu-se do seguinte problema: qual a (in)consistência na relação entre a BNCC e educação no/do campo, especialmente, no que se refere a realidade camponesa? Tendo como base a problemática, objetiva compreender a relação de (in)consistência entre a BNCC e a educação no/do campo no que se refere a realidade vivenciada pelos camponeses como condição fundamental para sua existência

Com o intuito de discutir a problemática apresentada e alcançar o objetivo, partiu-se de uma crítica à suposta aprovação da BNCC e a forma como ela direciona ensino/aprendizagem nos diferentes espaços, particularmente, o campo com toda a sua dinamicidade. Desse modo, trilhou-se pelo método materialismo histórico e dialético por considerar que é só possível compreender a dimensão de uma Base Comum Curricular por meio de um estudo que não se limite às aparências, mas à essência desse documento. Assim, de acordo com Netto (2011),

A aparência dos fenômenos é absolutamente importante porque começamos a conhecê-los a partir dela - o que não tem qualquer aparência não pode ser conhecido. Mas o conhecimento veraz, verdadeiro, parte da aparência dos fenômenos para encontrar a sua essência, a sua estrutura íntima e o seu movimento. (p. 335).

Para a viabilização da investigação, foram utilizados os seguintes procedimentos: Levantamento e análise bibliográfica: ocorre durante todo o período de realização da pesquisa, o levantamento, a leitura e a análise da bibliografia disponível, no sentido de buscar consistência teórica aos seus referentes básicos: BNCC, Educação no/do campo e agricultura camponesa em autores como: PRONKO, (2014); HILDALGO, (2008); MÉSZÁROS, (2008), CARDOSO, (1994); SOUZA, (2001), CALDART (2012); ALENTEJANO \& FIGOTTO (2012) dentre outros significativos.

A Análise documental: consideraram-se documentos como: Base Nacional Comum Curricular - três versões de 2015 a 2017, PNE - Plano Nacional de Educação 2014/2024, Diretrizes Operacionais para a Educação Básica nas Escolas do Campo, a LDB (Lei de Diretrizes e Base) 1996 e Resolução CNE/CEB 1, DE 3 DE ABRIL DE 2002.

Entende-se a pesquisa como processual, ou seja, no movimento do ir e vir, que significa abrir caminhos para além da experiência prática e imediata já que a atividade docente traz nela mesma a unidade teoria-prática e pode contribuir para a construção de um novo conhecimento, pois a ação do professor é uma prática que visa à transformação de uma realidade.

\section{ENSINOIAPRENDIZAGEM DIANTE DA PADRONIZAÇÃO DOS CURRÍCULOS PARA CIDADE E CAMPO}

O currículo é considerado o documento básico norteador das práticas pedagógicas dos professores. É de extrema importância e essencial no contexto escolar, quando se refere às atividades educativas, ações metodológicas e materiais utilizados no processo de interação professor e aluno na relação ensino e aprendizagem. Para Moreira (1997, p. 11): 
O currículo constitui significativo instrumento utilizado por diferentes sociedades tanto para desenvolver os processos de conservação, transformação e renovação dos conhecimentos historicamente acumulados como para socializar as crianças e os jovens segundo valores tidos como desejáveis. Em virtude da importância desses processos, discussão em torno do currículo assume cada vez mais lugar de destaque no conhecimento pedagógico (MOREIRA, 1997. p.11).

Nesse sentido, o currículo não se restringe aos conteúdos, envolve as ações e práticas efetivadas no espaço escolar com os sujeitos da práxis pedagógica. Ele é entendido, pois, como vivo, dinâmico e principalmente em construção com os que ele interage. Desse modo, o currículo das escolas do campo e das cidades deve ser construído e pensado com eles e para eles e não prontos sem sua participação.

Nessa perspectiva, com aprovação da BNCC, intensificam-se as ações que promovem a padronização dos currículos das escolas públicas e privadas, tanto do campo como da cidade. Nesse propósito, a "BNCC e currículos têm papéis complementares para assegurar as aprendizagens essenciais definidas para cada etapa da Educação Básica, uma vez que tais aprendizagens só se materializam mediante o conjunto de decisões que caracterizam o currículo em ação". (BRASIL 2017, p. 16).

No que se refere ao Ensino Médio, na formação geral básica, os currículos e as propostas pedagógicas devem garantir as aprendizagens essenciais definidas na BNCC. Conforme as DCNEM/2018, precisam contemplar, sem prejuízo da integração e articulação das diferentes áreas do conhecimento, estudos e práticas de:

I - língua portuguesa, assegurada às comunidades indígenas, também, a utilização das respectivas línguas maternas;

II - matemática;

III - conhecimento do mundo físico e natural e da realidade social e política, especialmente do Brasil;

IV - arte, especialmente em suas expressões regionais, desenvolvendo as linguagens das artes visuais, da dança, da música e do teatro;

V - educação física, com prática facultativa ao estudante nos casos previstos em Lei;

VI - história do Brasil e do mundo, levando em conta as contribuições das diferentes culturas e etnias para a formação do povo brasileiro, especialmente das matrizes indígena, africana e europeia;

VII - história e cultura afro-brasileira e indígena, em especial nos estudos de arte e de literatura e história brasileiras;

VIII - sociologia e filosofia;

IX - língua inglesa, podendo ser oferecidas outras línguas estrangeiras, em caráter optativo, preferencialmente o espanhol, de acordo com a disponibilidade da instituição ou rede de ensino (Resolução CNE/CEB n³/2018, Art. 11, § $4^{\circ}$ ).

A geografia enquanto ciência é completamente desconsiderada no que se refere a formação indispensável aos alunos do Ensino Médio, surgindo de forma ampla no Itinerário 
IV Ciências Humanas e Sociais aplicadas dando ênfase aos aspectos econômicos e a pluralidade, que significa negação da luta de classes.

\begin{abstract}
Aprofundamento de conhecimentos estruturantes para aplicação de diferentes conceitos em contextos sociais e de trabalho, estruturando arranjos curriculares que permitam estudos em relações sociais, modelos econômicos, processos políticos, pluralidade cultural, historicidade do universo, do homem e natureza, dentre outros, considerando o contexto local e as possibilidades de oferta pelos sistemas de ensino. (RESOLUÇÃO № 3, 2018 p 07). (Grifo Nosso).
\end{abstract}

Nessa perspectiva, Sousa (2015, p. 324), explica a BNCC como "[...] uma política de currículo que objetiva a definição de conteúdos básicos no contexto de um projeto currículo nacional". Consiste em uma política que irá definir os conteúdos básicos para a educação nacional, que pretende dar formação comum a todos os indivíduos.

Na BNCC, direitos e aprendizagem não são concebidos como pertencentes naturalmente aos sujeitos, mas como uma negação desses, uma vez que foram ligados à avaliação e ao fluxo escolar estipulado na meta sete ${ }^{1}$, pelo PNE - Plano Nacional de Educação. Assim, constata-se que os envolvidos na formulação desse documento não se preocuparam em diagnosticar a realidade das estruturas das escolas conforme gráfico que segue para pensar uma reforma.

Gráfico 01: Infraestrutura escolar - Petrolina - 2017

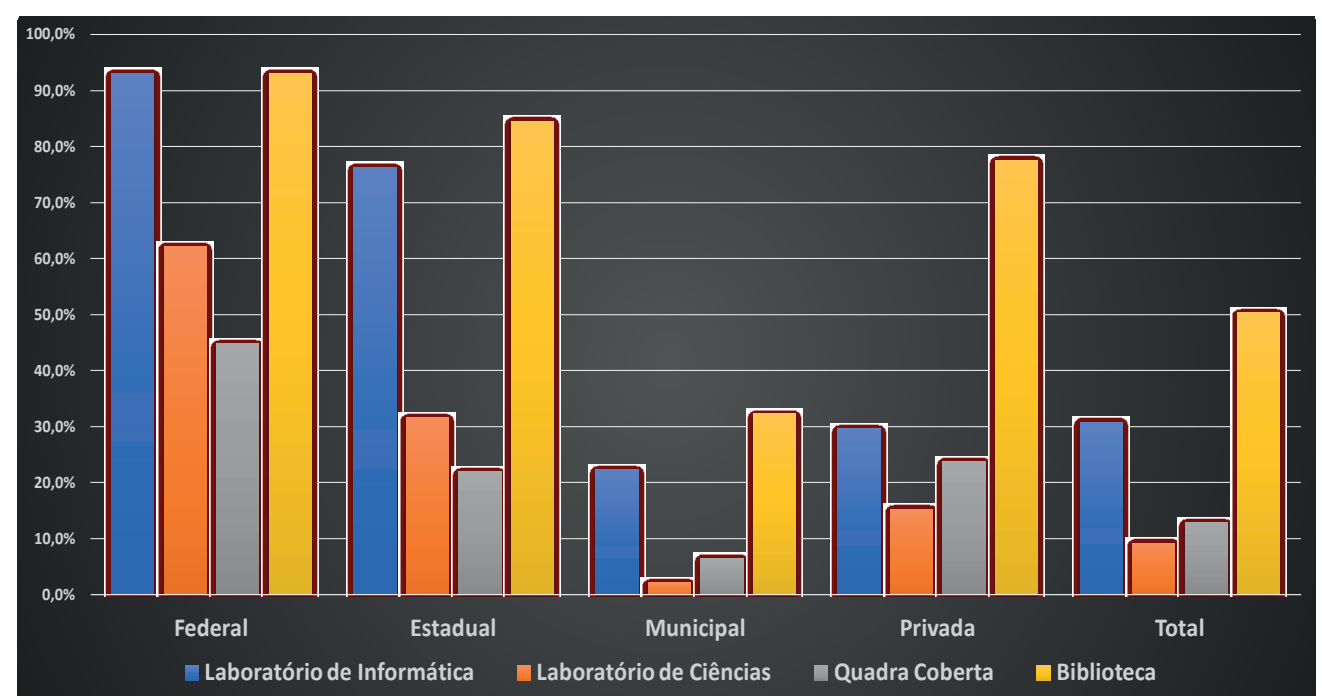

Fonte: Censo Escolar -2017 | Elaborado por: GIROTTO, Eduardo Donizeti, 2018.

1 A meta 7 objetiva - fomentar a qualidade da educação básica em todas as etapas e modalidades, com melhoria do fluxo escolar e da aprendizagem de modo a atingir as seguintes médias nacionais para o IDEB: IDEB - anos iniciais do Ensino Fundamental: 2015 - 5,2; 2017 - 5,5; 2019 -5,7; 2021 - 6,0. Anos finais do Ensino Fundamental: 2015 - 4,7; 2017 - 5,0; 2019 - 5,2; 2021 - 5,5. Ensono Médio: 2015 - 4,3; 2017 - 4,7; 2019 - 5, 0; 2021 - 5,2. (Grifo nosso) Disponível em: https://novaescola.org.br/conteudo/3003/pne-meta-7. Acesso em: 16 jun..2018. 
As escolas das redes de ensino do Estado de Pernambuco, com exceção dos Institutos Federais (IFs), apresentam deficiências de infraestrutura básica necessárias para garantir acesso à aprendizagem. Por essa razão, observa-se que menos de $10 \%$ do total das escolas possui laboratório de ciências e, ainda, revela ausência de bibliotecas, quadra coberta e laboratório de informática em mais de $50 \%$ dos estabelecimentos de ensinos. Essa disparidade aumenta quando são apresentados esses mesmos dados, comparando as escolas localizadas no campo e as da cidade como mostra o gráfico a seguir:

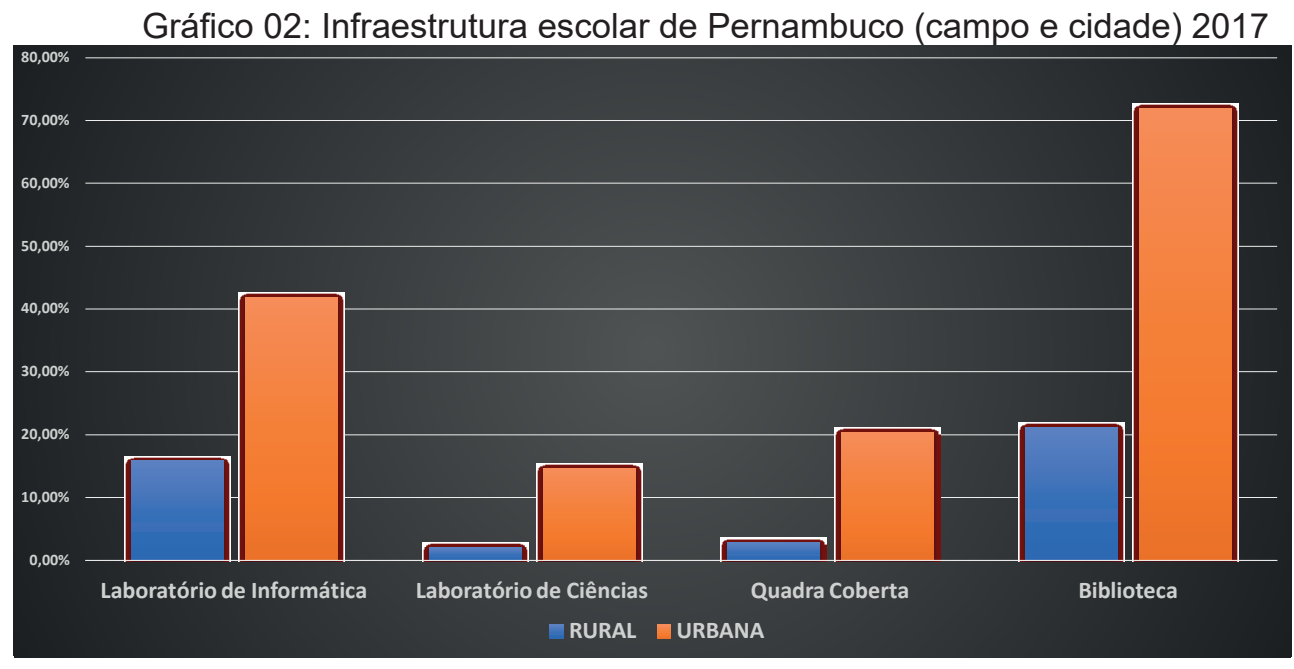

Fonte: Censo Escolar -2017 | Elaborado por: GIROTTO, Eduardo Donizeti, 2018.

Observa-se que, de forma geral as escolas das redes de ensino de Pernambuco têm infraestrutura deficiente e, ainda, mais precárias quando se trata daquelas localizadas no campo, o que significa um ensino mais deficitário nesse espaço com a consolidação da BNCC.

No que tange à formação docente, não é perceptível, já que, por trás disso, encontra-se a abertura para grupos privados atuarem na educação.

Gráfico 03: formação docente Pernambuco - 2017

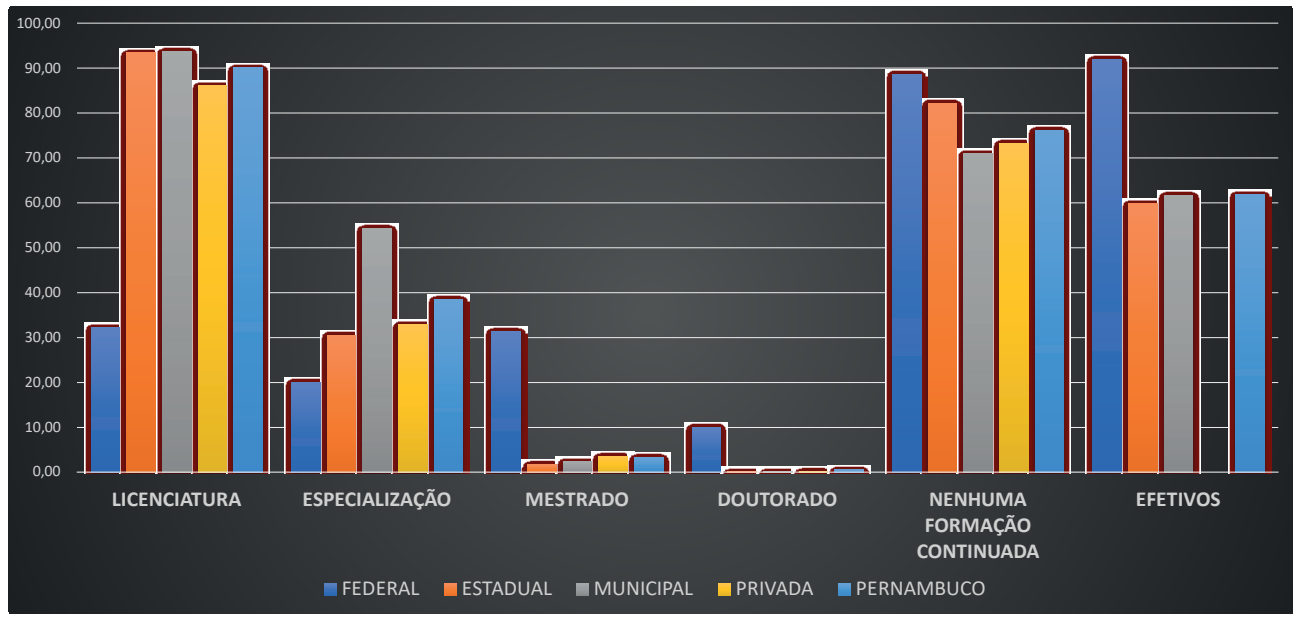

Fonte: Censo Escolar -2017 | Elaborado por: GIROTTO, Eduardo Donizeti, 2018. 
Os professores das redes de ensino do Estado de Pernambuco têm formação predominante inicial com licenciaturas, que diminui em relação ao quantitativo que apresentam especializações e, mais ainda, em relação ao mestrado e doutorado. A realidade do gráfico ilustra que as condições de trabalhos não satisfatórias na Educação Básica distanciam os professores da universidade, ou seja, da formação continuada.

Seguindo essa linha de raciocínio, Sousa (2015) relata que os representantes do Governo, órgãos como a UNDIME (União Nacional dos Dirigentes Municipais de EducaÇão); CONSED (Conselho Nacional de Educação); UNCME (União dos Conselhos Municipais de Educação), empresas, institutos e fundações são os incumbidos na elaboração da BNCC, com a convicção de que:

\begin{abstract}
A performance do estudante brasileiro será resultado de um currículo nacional selecionando para fins do mercado numa concepção de educação produtivista com base na lógica empresarial, na qual os alunos são tratados como produtos que precisam ser lapidados para serem mão de obra em contextos do capitalismo periférico. (SOUSA, 2015, p. 332).
\end{abstract}

Dentro desse contexto, a autora posiciona-se contrária à ideia de padronização do currículo, destacando que o currículo comum satura a diversidade cultural do povo brasileiro, bem como busca regular o sujeito que pretende formar e, com isso, sufoca sua singularidade e subjetividade.

Nesse sentido, as ações e práticas que compõem o currículo das escolas refletem em seu dia a dia, identificando se existe o desenvolvimento de um trabalho de formação dinâmica, focado no diálogo cultural e contextualizado com as realidades dos alunos. Dessa forma, a preocupação não é somente se todos têm direito à escola, mas também com o que está sendo ensinado nela.

Assim, os movimentos sociais do campo, principalmente o MST (Movimento dos Trabalhadores Sem Terra) foram à luta por uma escola que proporcionasse um ensino diferente e é daí que nasce ideia de Educação do Campo durante a realização do Encontro Nacional de Educadoras e Educadores da Reforma Agrária - ENERA, promovido pelo Movimento dos Trabalhadores Rurais Sem Terra (MST) no ano de 1997 em parceria com outras entidades. Para se chegar à ideia, foram realizados estudos e pesquisa sobre a realidade do campo e, a partir dessa práxis, começa a nascer o conceito de Educação do Campo, especialmente, pelas experiências construídas pelos movimentos camponeses e organizações correlatas por meio do PRONERA - Programa Nacional de Educação na Reforma Agrária, que surge em 1997. Assim,

A essência da Educação do Campo não pode ser apreendida senão no seu movimento real, que implica um conjunto articulado de relações (fundamentalmente contradições) que a constituem como prática/projeto/política de educação e cujo 
sujeito é a classe trabalhadora do campo. (CALDART, ALENTEJANO \& FRIGOTTO, 2012 p. 13).

Com esse entendimento, os movimentos sociais organizados passaram a confrontar uma concepção de educação e lutar por outra que garanta o acesso ao conhecimento; portanto, que ela seja no e do campo. Para Caldart (2012) "No: o povo tem direito de ser educado no lugar onde vive; Do; o povo tem direito a uma educação pensada desde seu lugar e com sua participação vinculada à sua cultura e às suas necessidades humanas e sociais". (p.18). É importante frisar que "é a existência do confronto que essencialmente define a Educação do Campo e torna mais nítida sua configuração como um fenômeno da realidade atual”. (CALDART, ALENTEJANO \& FRIGOTTO, 2012 p. 14).

Dessa maneira, é importante destacar a necessidade do ensino voltado para atender às especificidades do campo já que eles, envolvidos na luta, não aceitam, práticas pedagógicas simplistas, reducionistas e alienantes, mas, pelo contrário, eles lutam por uma escola pública de qualidade que promova ensino emancipador; é na escola onde a emancipação pode e deve acontecer.

Numa perspectiva contrária à Educação do Campo, a BNCC enfatiza que, "ao longo da Educação Básica, as aprendizagens essenciais definidas na BNCC devem concorrer para assegurar aos estudantes o desenvolvimento de dez competências gerais, que consubstanciam, no âmbito pedagógico, os direitos de aprendizagem e desenvolvimento". (BRASIL 2017, p. 08).

Dentre essas competências, a primeira apresenta: "valorizar e utilizar os conhecimentos historicamente construídos sobre o mundo físico, social, cultural e digital para entender e explicar a realidade, continuar aprendendo e colaborar para a construção de uma sociedade justa, democrática e inclusiva" (BRASIL 2017, p.09). Essa competência entra em contradição com o princípio da BNCC, que é a padronização curricular em todo país. Assim, os conhecimentos historicamente construídos pelos estudantes, ainda que mostrem que eles serão contemplados nos $40 \%$, referentes às particularidades locais, não se tem uma garantia como as Secretarias Estaduais e Municipais operacionalizarão o dia a dia das escolas.

Assim, o conceito de competência é definido na BNCC como mobilização de conhecimento e habilidades, atitudes e valores, que auxiliam nas demandas da vida diária, atendendo extremamente às exigências do mundo do trabalho, transformando a escola numa instituição formadora de sujeitos para atender unicamente ao mercado.

No âmbito educacional, a concepção de competência tem se disseminado de acordo com as perspectivas de valorização do saber fazer do indivíduo nas relações do trabalho obtido ao longo da vida. Com esse propósito, as escolas passam a formar pessoas capacitadas apenas para o mercado de trabalho no processo produtivo capitalista, assim "o investimento em educação deve estar mais voltado para as 'oportunidades de aprendizagem', favorecendo mercados de formação que promovam a disseminação das competências e das capacidades individuais necessárias para o desenvolvimento". (PRONKO, 2014 p. 108). 
Nessa perceptiva, o currículo promovido pela BNCC não contempla o ensino contextualizado do campo, pois, no campo, a vida cotidiana dos camponeses é marcada por elementos que os caracterizam: a) força de trabalho familiar; b) trabalho acessório; c) trabalho assalariado; d) propriedade da terra; e) socialização camponesa; f) meios de produção; g) jornada de trabalho. Os referidos elementos não podem ficar fora, mas dentro dos currículos das escolas, de modo que eles sejam os norteadores do processo ensino-aprendizagem.

Assim, a BNCC enfatiza uma política educacional fundada em resultados promovidos pelas avaliações externas como o SAEB (Sistema de Avaliação da Educação Básica), que avaliam o desempenho dos alunos dos anos finais do Ensino Fundamental e Médio. A rede de ensino de Pernambuco tem avaliação própria denominada de SAEPE (Sistema de Avaliação da Educação Básica de Pernambuco).

Assim, verificamos que as ações voltadas para divulgação de resultados das provas externas, como o SAEB, SAEPE e do ENEM (Exame Nacional do Ensino Médio) funcionam como termômetro para indicar a qualidade dos resultados dos ensinos brasileiros; também coincidem com as conjecturas do BM e com justificativas do Governo em criar uma Base Nacional Comum Curricular.

A centralidade do Sistema Nacional de Avaliação da Educação Básica (SAEB), aliado agora ao Exame Nacional do Ensino Médio (ENEM) e ao Provão, consolidou o uso da informação, da estatística e da avaliação como principais instrumentos de política educacional durante toda a sua gestão (SOUZA, 2005, p. 116).

Essas avaliações externas servem como álibi para justificar a existência da BNCC e promover a padronização dos currículos. Sendo assim, um desrespeita a legislação que dá base legal à Educação do Campo, a exemplo do art.02, das Diretrizes Operacionais para Educação do Campo (Resolução CNE/CEB 1, de 3 de Abril de 2002), sendo essas uma conquista da luta dos movimentos sociais do campo principalmente do MST (Movimento dos Trabalhadores Rurais Sem-Terra). Nela, é garantido que:

[...] A identidade da escola do campo é definida pela sua vinculação às questões inerentes à sua realidade, ancorando-se na temporalidade e saberes próprios dos estudantes, na memória coletiva que sinaliza futuros, na rede de ciência e tecnologia disponível na sociedade e nos movimentos sociais em defesa de projetos que associem as soluções exigidas por essas questões à qualidade social da vida coletiva no país. (DIRETRIZES, 2002. Art. $2^{\circ}$, p. 01).

Nesse sentido, a Base reforça a continuidade de um modelo que já deveria ter sido superado. De acordo com Arroyo (2004, p.56),

Com muita lucidez os movimentos sociais do campo desconfiam que seus direitos à educação, ao conhecimento, à cultura, aos valores, às formas de sociabilidade sejam deixados por conta dessas políticas "modernizadoras", inspiradas no negócio, no lucro privado e na destruição da agricultura camponesa. (p.56). 
A autonomia do ensino, mesmo que ainda esteja em processo de conquista absoluta, é o avanço mais importante da luta dos movimentos sociais do campo, sendo fundamental para construção do currículo significativo que esteja inserido na realidade vivenciada pelos sujeitos do campo.

\title{
3 A BNCC E O CICLO AGRÍCOLA - A REALIDADE CAMPONESA
}

A Educação do Campo tem como proposta a inclusão da população camponesa como protagonista de um projeto educacional, que propõe, entre outros, adequação do período de férias com a época do plantio, colheita e safras. De fato, o trabalho do campo realizado pelos alunos conta com calendário escolar, que deve ser adequado com o ciclo agrícola. De acordo com a LDB (Lei de Diretrizes e Bases), mais especificamente no segundo parágrafo do art.28, ressalta:

\footnotetext{
Na oferta de educação básica para a população rural, os sistemas de ensino promoverão as adaptações necessárias à sua adequação às peculiaridades da vida rural e de cada região, especialmente:

I - conteúdos curriculares e metodologias apropriadas às reais necessidades e interesses dos alunos da zona rural;

II - organização escolar própria, incluindo adequação do calendário escolar às fases do ciclo agrícola e às condições climáticas;

III - adequação à natureza do trabalho na zona rural. (BRASIL 1996, p. 21).
}

No contexto da escrita da LDB - faz-se menção à educação rural; no entanto, serve de amparo na luta por uma Educação do Campo. Ainda, nessa conjuntura, é apresentado no art.23, o sistema de Alternância que tem como preceito básico o ensino com a vida no campo. Assim:

\begin{abstract}
A educação básica poderá organizar-se em séries anuais, períodos semestrais, ciclos, alternância regular de períodos de estudos, grupos não seriados, com base na idade, na competência e em outros critérios, ou por forma diversa de organização, sempre que o interesse do processo de aprendizagem assim o recomendar.

$\S 1^{\circ} \mathrm{A}$ escola poderá reclassificar os alunos, inclusive quando se tratar de transferências entre estabelecimentos situados no país e no exterior, tendo como base as normas curriculares gerais.

$\S 2^{\circ} \mathrm{O}$ calendário escolar deverá adequar-se às peculiaridades locais, inclusive climáticas e econômicas, a critério do respectivo sistema de ensino, sem com isso reduzir o número de horas letivas previsto nesta Lei. (BRASIL 1996, p.17) (Grifo nosso).
\end{abstract}

Dentro desse contexto, os movimentos sociais do campo, principalmente o MST (Movimento dos Trabalhadores Sem Terra), contribuíram para aprovação das Diretrizes Operacionais para a Educação Básica nas Escolas do Campo. Concretizada pelo Conselho 
Nacional de Educação câmara de educação básica resolução CNE/CEB 1, de 03 de abril de 2002. Assim, referindo-se à realidade camponesa, o art. $7^{\circ}$ relata que:

É de responsabilidade dos respectivos sistemas de ensino, através de seus órgãos normativos, regulamentar as estratégias específicas de atendimento escolar do campo e a flexibilização da organização do calendário escolar, salvaguardando, nos diversos espaços pedagógicos e tempos de aprendizagem, os princípios da política de igualdade. (p.02).

Já o inciso $\S 1^{\circ}$ dessa mesma resolução menciona os artigos da LDB citados anteriormente neste trabalho em que relata: "o ano letivo, observado o disposto nos artigos 23 , 24 e 28 da LDB, poderá ser estruturado independente do ano civil”. (BRASIL, 2002 p. 02).

As conquistas de legislação que amparam, ao mesmo tempo, da legalidade à adequação do calendário escolar à realidade camponesa, possibilitam que o aluno, filho de camponês, continue auxiliando nos trabalhos junto com sua família no campo e nos manejos com os animais, o que corresponde à principal característica da produção camponesa. Nessa perspectiva, os trabalhadores sem-terra passaram a lutar não somente por terra, mas por educação diferente da institucionalizada pelo Estado.

Diferente dessa perspectiva, oito pontos denominados de "decisões vão adequar as proposições da BNCC à realidade local, considerando a autonomia dos sistemas ou das redes de ensino e das instituições escolares, como também o contexto e as características dos alunos" (BRASIL, 2017 p.16).

Referindo-se aos oitos pontos ou decisões escritos na BNCC, a mesma esclarece:

Essas decisões precisam, igualmente, ser consideradas na organização de currículos e propostas adequados às diferentes modalidades de ensino (Educação Especial, Educação de Jovens e Adultos, Educação do Campo, Educação Escolar Indígena, Educação Escolar Quilombola, Educação a Distância), atendendo-se às orientações das Diretrizes Curriculares Nacionais. (BRASIL, 2017 p.17).

Existe um estudo no Conselho Nacional de Educação (CNE) para que o Ensino Médio tenha parte de sua carga horária a distância no modelo EAD (Educação a Distância). Desse modo, observa-se que a BNCC cita a Educação do Campo, sujeita à proposta do ensino EAD, e, ainda, discorre que é preciso adequar a proposta da Base com diferentes modalidades de ensino, algo que dificultaria em muito a aprendizagem do campo, já que é um sistema que necessita do uso da internet e muitos dos assentamentos, acampamentos ou o campo, de modo geral, não possuem tecnologia suficiente para esse fim.

Assim, a Educação do Campo é revolucionária no sentido de se opor à educação institucionalizada. Ela surgiu dentro da luta camponesa pela reforma agrária como condição para se viver no campo. Desse modo, ela não pode ser controlada pela BNCC, pois é um documento balizador, normativo e propõe o que deve ser ensinado, conduzindo as escolas a um padrão de ensino imposto. 


\subsection{A Escola Estadual Malaquias Mendes da Silva Entre o Cumprimento da BNCC e o Ser Camponês.}

O Ensino Médio no Distrito de Rajada é ministrado pela Escola Estadual Malaquias Mendes da Silva, circunscrita precisamente no povoado de Atalho, onde se localiza a sede da escola, e as extensões estão localizadas nos povoados de Caititu com 12 km de distância, e no Distrito de Rajada a 30 km. Juntas, tais comunidades representam uma extensão geográfica de mais da metade da área de sequeiro do referido município, com aproximadamente 15 mil habitantes e um contingente de mais de 500 estudantes.

A escola em questão possui um quadro de matrícula com alunos oriundos de famílias camponesas; no entanto, não oferece um ensino voltado para os povos do campo, e os docentes não são formados pedagogicamente para atender a essa demanda.

Mapa 01: localização da escolar Malaquias Mendes da Silva
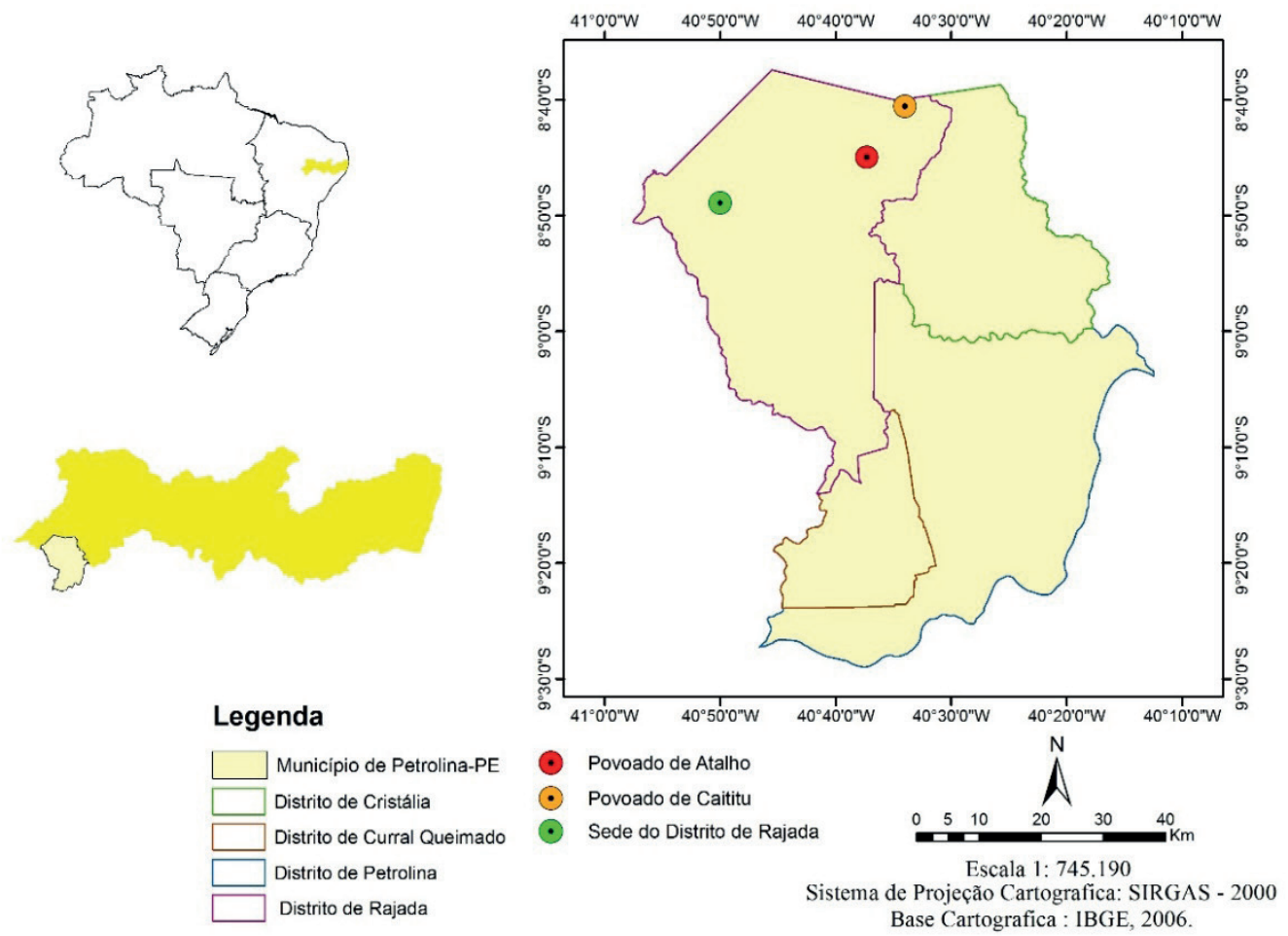

Fonte: GTMAGEO- Grupo de Trabalho em Monitoramento Geotecnologia

Elaborado por: LOPES, Rodrigo Jose de Carvalho.

A sede do distrito de Rajada está localizada a $80 \mathrm{~km}$ da cidade de Petrolina; por ser uma área de sequeiro, os efeitos das estiagens, muito comuns no sertão nordestino, são bastante acentuados. Com isso, a agricultura e a pecuária são baseadas na produção familiar. Assim, a escola Malaquias Mendes da Silva, mesmo oferecendo o ensino regular, tem o privilégio de estar num contexto em que a presença da cultura camponesa é constante. 
Sendo assim, para diagnosticar a relação de (in) consistente da BNCC com a realidade camponesa, realizou-se, na Escola Estadual Malaquias Mendes da Silva, uma pesquisa com os professores de Geografia e História, conforme gráfico, para esclarecimento da problemática do projeto.

Gráfico 04: Formação dos professores

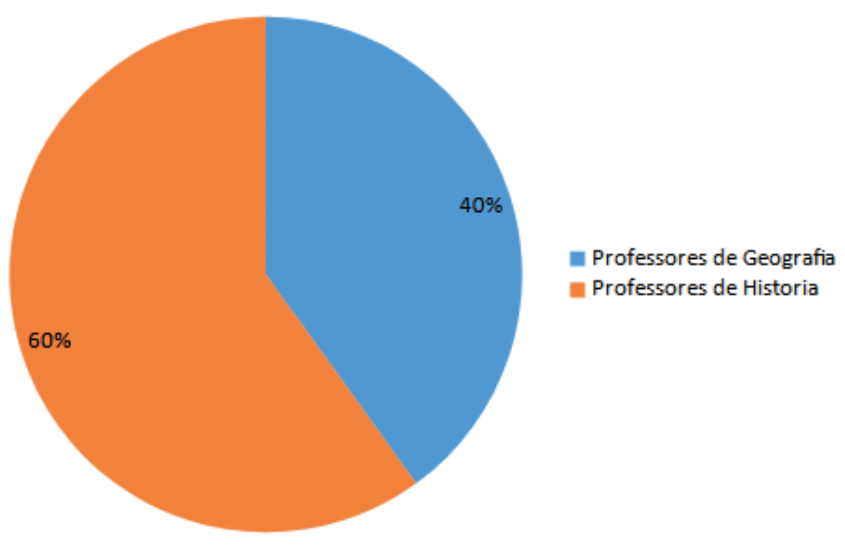

Fonte: Pesquisa de campo 2018. | Elaboração: AMORIM, Alberto Filho Coelho de. 2018

Referente ao acesso dos professores, a Escola Estadual Malaquias Mendes da Silva, principalmente a sede, que está localizada no Povoado de Atalho, como também a extensão localizada na comunidade de Caititu, destaca-se que o difícil acesso implica uma das dificuldades em encontrar professores que permaneçam durante toda a semana em um desses espaços.

Gráfico 05: Residência dos professores em relação à localização das escolas

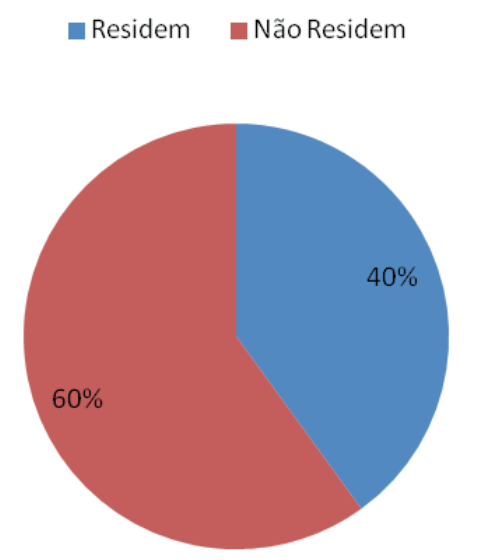

Fonte: Pesquisa de campo 2018. | Elaboração: AMORIM, Alberto Filho Coelho de. 2018.

A não residência dos docentes impede o acesso ao cotidiano dos alunos que diferem da realidade urbana. As relações afetivas e as particularidades da vida do campo são mais fáceis quando o professor é um integrante da comunidade e mora nela, ou seja, participa dos festejos típicos, colheita dentre outros. 
A educação centrada no campo para seus sujeitos tem como protagonista o próprio camponês e, com isso, nota-se a importância das aulas serem ministradas por professores que não só vivem na comunidade, mas também que sejam convictos da necessidade de um ensino direcionado para esse fim. Nesse sentido, é que se acredita que a Educação do Campo,

[...] visa incidir sobre a política de educação desde os interesses sociais das comunidades camponesas. Objetivo e sujeitos a remetem às questões do trabalho, da cultura, do conhecimento e das lutas sociais dos camponeses e ao embate (de classe) entre projetos de campo e entre lógicas de agricultura que têm implicações no projeto de país e de sociedade e nas concepções de política pública, de educação e de formação humana. (CALDART, 2012 p.259).

A construção da Educação do Campo configura uma das práticas políticas de ensino dos trabalhadores do campo, que confronta com o modelo capitalista de exploração do trabalho pelo capital, resistindo por meio do modo particular de organizar a vida e produzir seus alimentos com autonomia, em harmonia com a não destruição da natureza. Dentro dessa linha de raciocínio, solicitou-se dos entrevistados que diferenciassem Educação no campo e do campo. Eles responderam que: "A educação no campo é aquela que é desenvolvida no campo e segue as diretrizes do país. A educação do campo é trabalhada no campo e tem programa especifico do campo". (Professor E- Informação escrita - Entrevista 5). "No Campo, é local onde as pessoas residem, do Campo, conhecimentos trabalhados sobre o campo". (Professor A- Informação escrita - Entrevista 1)2. "Educação do campo tem conteúdos e metodologias apropriadas às reais necessidades do aluno conforme o artigo 28 da LBD. Educação no campo vem metodologias mais prontas e acabadas". (Professor B- Informação escrita - Entrevista 2). "No campo, é aquela escola que se encontra no espaço rural, já do Campo ensina os cuidados com a terra". (Professor C- Informação escrita Entrevista 3). "No campo, funcionam com base nas Diretrizes Nacionais. Do campo funciona com conteúdos específicos do campo". (Professor D- Informação escrita Entrevista 4)

Percebe-se, na fala dos professores, que o conceito de Educação do Campo, ora se aproxima, ora se distancia do que é utilizado neste trabalho, uma vez que aqui apresenta a Educação do Campo como uma conquista por meio da luta camponesa, com um ensino construído com os sujeitos e não para eles, para, assim, conquistar o ensino, livre de manipulação ideológica. Por essa razão:

2 Entrevistas 1, 2, 3, 4, e 5 - concedida por professores em [Abril/2018]. Entrevistador: Alberto Filho Coelho de Amorim. Petrolina, 2018. 
A realidade que produz a Educação do Campo não é nova, mas ela inaugura uma forma de fazer seu enfrentamento. Ao afirmar a luta por políticas públicas que garantam aos trabalhadores do campo o direito à educação, especialmente à escola, e a uma educação que seja no e do campo. (CALDART, 2012 p. 261).

Evidenciam-se termos contraditórios na denominação de quase todos os professores, fazendo uma mistura de Educação do Campo com outros tipos de ensino ofertados para a campo, com exceção do professor B, que respondeu fundamentado na LDB; contudo, verificou-se que os professores da disciplina de Ciências Humanas da escola Estadual Malaquias Mendes da Silva têm vago conhecimento sobre o conceito de Educação do Campo, pois, ao serem questionados se eles têm formações pedagógicas voltadas para realidade dos sujeitos do campo, $100 \%$ responderam que não.

Nas respostas dos docentes, evidencia-se que a escola necessita ter um ensino que atenda aos anseios da comunidade em que ela está inserida, sendo necessário construir uma proposta pedagógica diferente que se aproxime do dia a dia da comunidade, que tem, no campo, a condição de sua existência.

[...] temos afirmado que a especificidade da Educação do Campo está no campo (nos processos de trabalho, na cultura, nas lutas sociais e seus sujeitos concretos) antes que na educação, mas essa compreensão já supõe uma determinada concepção de educação: a que considera a materialidade da vida dos sujeitos e as contradições da realidade como base da construção de um projeto educativo, visando a uma formação que nelas incida. A realidade do campo constitui-se, pois, na particularidade dada pela vida real dos sujeitos, ponto de partida e de chegada dos processos educativos. Todavia, seu horizonte não se fixa na particularidade, mas busca uma universalidade histórica socialmente possível. (CALDART, ALENTEJANO \& FRIGOTTO, 2012 p. 14).

As contradições sobre a Educação do Campo, apresentadas pelos professores das disciplinas de Histórias e Geografia da escola Malaquias Mendes da Silva, também têm origem num contexto, de falta de conhecimento sobre a legislação que dá amparo legal e a luta que promoveu essas conquistas, o que é demonstrado no gráfico a seguir: 
Gráfico 06: conhecimento dos docentes a respeito das diretrizes que regem a educação do campo

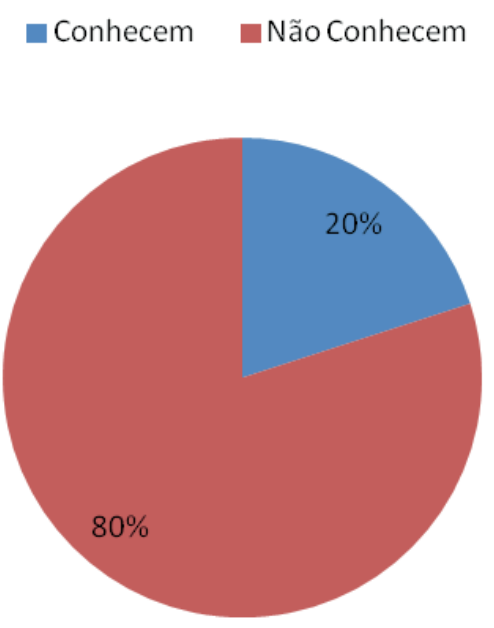

Fonte: Pesquisa de campo 2018. | Elaboração: AMORIM, Alberto Filho Coelho de. 2018.

Com a implantação da BNCC para Ensino Fundamental, e com o possível direcionamento desse documento para o Ensino Médio, as escolas que têm realidades semelhantes à da Escola Estadual Malaquias Mendes da Silva, terão um distanciamento maior entre o que está sendo ensinado aos alunos e o modo de vida dos camponeses. Macedo (2014) e Freitas (2016) consideram a BNCC como um documento decorrente das façanhas das políticas educacionais direcionadas a construir uma educação mercadológica, promovedora de lucro.

No tocante à realidade camponesa, foi questionado se, com a implantação da BNCC, é possível construir uma proposta alternativa de currículo voltada para a realidade da escola, ou seja, a realidade camponesa, as respostas seguem:

Gráfico 07: Construção de uma proposta alternativa para a escola com implantação da BNCC

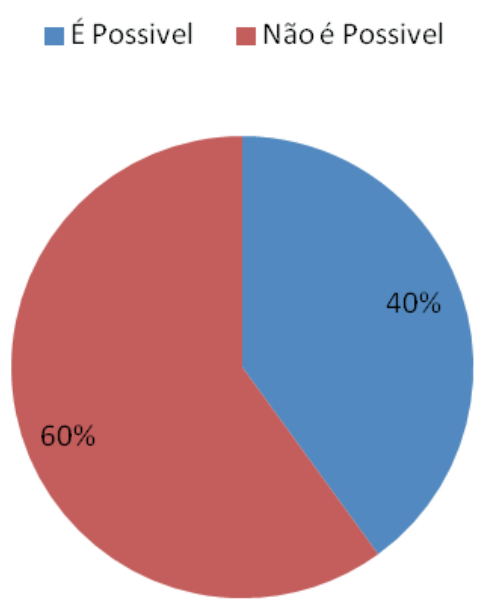

Fonte: Pesquisa de campo 2018. | Elaboração: AMORIM, Alberto Filho Coelho de. 2018. 
Dos docentes entrevistados $60 \%$ não acreditam que, com a implantação BNCC, é possível a construção de proposta de ensino voltada para educação no campo; $40 \%$ afirmam que sim; no entanto, $100 \%$ dos entrevistados afirmam que é importante construir uma proposta alternativa de currículo voltada para a realidade da escola, ou seja, a realidade camponesa.

Ao questionar se à BNCC contempla as realidades da cidade e do campo, $100 \%$ dos professores asseguram que não; no entanto, eles acreditam que esse documento foi elaborado por profissionais que residem nas cidades e que ela está voltada a propagar os interesses e o estilo de vida urbana.

Com base no entendimento dos docentes, percebeu-se que a compreensão da realidade vem a partir de possibilidades ainda não desenvolvidas historicamente, mas indicadas por seus sujeitos ou pelas transformações em curso em algumas práticas educativas concretas e na forma de construir políticas de educação. (CALDART, 2012).

\section{A (IN)CONSISTÊNCIA DA BASE PARA UMA EDUCAÇÃO NO/DO CAMPO}

Constantemente, as propagandas na mídia referentes à BNCC mostram que ela é um instrumento que promoverá a qualidade do ensino, levando as pessoas a acreditarem que todos os problemas que impedem a aprendizagem dos alunos serão solucionados quando ela for implantada. Essa concepção é reforçada nos conteúdos, particularmente, os de Geografia anos finais do Ensino Fundamental que deverão ser estendidos ao Ensino Médio.

A BNCC da área de Ciências Humanas e Sociais Aplicadas - integrada por Filosofia, Geografia, História e Sociologia - propõe a ampliação e o aprofundamento das aprendizagens essenciais desenvolvidas no Ensino Fundamental, sempre orientada para uma formação ética. Tal compromisso educativo tem como base as ideias de justiça, solidariedade, autonomia, liberdade de pensamento e de escolha, ou seja, a compreensão e o reconhecimento das diferenças, o respeito aos direitos humanos e à interculturalidade, e o combate aos preconceitos de qualquer natureza. (BNCC, 2018 p.547).

No ensino Fundamental, os conteúdos são assim distribuídos:

1. O sujeito e seu lugar no mundo - focaliza-se as noções de pertencimento e identidade, [...] valorizando-se os contextos mais próximos da vida cotidiana (BNCC, 2017, p. 358). Esse conteúdo requer um conhecimento da realidade em que a escola e os sujeitos da práxis pedagógica estão inseridos. Cada realidade precisa ser trabalhada, tanto da cidade como particularmente no campo. Assim:

A intenção é fazer uma educação que privilegie a realidade rural, as questões específicas dessa realidade, de modo que ajude a superar a dicotomia entre campo e 
cidade, contribuindo para superar discriminações e preconceitos próprios da estrutura social capitalista (FERRARO e RIBEIRO, 2002, p. 95).

2. Em Conexões e Escalas - relata a compreensão de fatos locais e globais e encontra-se relacionada com o entendimento das análises entre espaços e escalas. O conteúdo da unidade requer que nada seja trabalhado somente na dimensão local sem articulação com as demais escalas.

o espaço mais significativo para a Geografia é o que se apresenta como uma totalidade, no qual ocorrem relações econômicas, políticas e sociais em escalas local, regional, nacional e global. O espaço geográfico, que corresponde ao espaço que está sendo ou foi produzido pelos seres humanos, se relaciona com a dinâmica da natureza e com o contínuo movimento de transformação da sociedade. Sendo um espaço social, expressa o trabalho humano, as relações e as práticas sociais que se sucederem no tempo. (TERRA; COELHO, 2005 p. 15).

O espaço é social por expressar o trabalho humano e as relações e práticas de uma sociedade com dados, recorte espacial e temporal. Com isso, a escala por meios desses elementos vai além da localização e a mensuração dos fenômenos. Ela analisa e debate as representações cartográficas e aponta as variáveis e os resultados, que, não são apenas físicos, mas resultados das relações humanas.

Tal escala, ainda, é pouco debatida e trabalhada metodologicamente no Ensino Básico. São poucos os livros didáticos de Geografia que tratam de escala com resultados direcionados para as relações humanas. Restringe mostrar que ela é composta pelas escalas local, regional, nacional e global, mas sem qualquer diagnóstico de como aplicá-la metodologicamente na análise dos fenômenos geográficos e com a BNCC não será diferente, estudar escala continuará ofusco e sem análise.

3. O Mundo do trabalho - nessa unidade, o foco encontra-se na transformação "do espaço agrário e industrial em sua relação entre campo e cidade, destacando-se as alterações provocadas pelas novas tecnologias no setor produtivo, fator desencadeador de mudanças substanciais nas relações de trabalho, na geração de emprego e na distribuição de renda em diferentes escalas". (BNCC, 2016 p.359). Percebe-se que há uma ênfase na tecnologia como imprescindível ao setor produtivo, geração de emprego e distribuição de renda. É importante destacar que a tecnologia empregada no campo pelas grandes corporações ligadas ao agronegócio provoca desapropriação dos camponeses já que, para garantir a produção e produtividade, necessita da terra e da tecnologia seja, por meio da máquina e do uso de agrotóxicos. "Os trabalhadores que estão sendo substituídos por máquinas e novas tecnologias estão engrossando a massa dos desempregados crônicos, sem possibilidades de colocação no mercado, poderão ser eliminados por algum tipo de conflito no futuro" (CARVALHO, 2010 p.68). 
As tecnologias usadas no campo para garantir o "desenvolvimento" e a expansão do agronegócio, atingiram os camponeses fortemente, ao invés de promover o aumento da oferta de trabalho, trouxe o desemprego, expropriação e, consequentemente, conflitos no campo.

4. Formas de representação e pensamento espacial - espera-se que, no decorrer do Ensino Fundamental, os alunos tenham domínio da leitura e elaboração de mapas e gráficos, iniciando-se na alfabetização cartográfica. Fotografias, mapas, esquemas, desenhos, imagens de satélites, audiovisuais, gráficos, entre outras alternativas, são frequentemente utilizados no componente curricular. (BNCC, 2016 p.359).

No tocante ao ensino das representações espaciais, não é por meio de cópias/reproduções de mapas sem qualquer finalidade específica que os alunos aprendem a usar esse recurso; no entanto, se tiver um trabalho direcionado para sua própria construção, será uma oportunidade para se debater com os alunos sobre o lugar, a paisagem, o relevo, o clima, o centro, a periferia, o local-global, dentre outros.

Compreende-se que os fatos do cotidiano podem influenciar diretamente na relação ensino-aprendizagem, como Oliveira (2008) esclarece que a escala local deve ser considerada na construção de mapas locais pelos alunos:

Utilizar os mapas do atlas apenas como transmissão de conhecimentos elimina a possibilidade de participação e elaboração por parte dos alunos de um novo conhecimento sobre o lugar, sobre a sua localidade, o que pode vir a impedir uma análise e compreensão da Geografia local (OLIVEIRA, 2008, p. 491).

A leitura e a compreensão de um mapa devem ser o alvo principal do trabalho do professor; esse, por sua vez, deve fazer com que os alunos interajam com o conceito de mapa, passando por sua confecção até seu sentido e funções, a fim de facilitar comparação ou interpretações.

5. Natureza, ambientes e qualidade de vida - a unidade concentra-se no conhecimento e nos fundamentos "naturais do planeta e as transformações impostas pelas atividades humanas na dinâmica físico-natural, inclusive no contexto urbano e rural". (BNCC, 2016 p.360).

Qualidade de vida está intimamente ligada ao respeito e à preservação da natureza, pois é imprescindível que as atividades de produção estejam intencionalmente voltadas para manutenção da vida humana e a preservação da natureza. Todavia, o que acontece na realidade é a exploração do homem e dos recursos naturais para acúmulo do capital por aqueles que mantêm sobre suas posses os meios de produção.

A degradação da natureza ou a dor da devastação social não têm qualquer significado para seu sistema de controle sociometabólico, em relação ao imperativo absoluto de sua autorreprodução numa escala cada vez maior. É por isto que durante o seu desenvolvimento histórico se excedeu o capital em todos os planos - incluído 
seu relacionamento com as condições básicas da reprodução sociometabólica -, mas estava destinado a fazê-lo cedo ou tarde. (MÉSZÁROS, 2011, p. 253).

A vida do homem e, também, do planeta Terra, está em risco, pois os recursos naturais fundamentais para manutenção humana, como a água dos rios, as florestas dentre outros, estão sendo exploradas intensamente e, com isso, estão se esgotando. A BNCC não relaciona essa problemática com o sistema econômico que impera nos país, apenas faz relata superficialmente.

Desse modo, a BNCC do Ensino Fundamental garante que as temáticas contidas nos conteúdo da disciplina Geografia do Ensino Fundamental ( $O$ sujeito e seu lugar no mundo; Conexões e escalas; Mundo do trabalho; Formas de representação e pensamento espacial; Natureza, ambientes e qualidade de vida) são suficientes para os estudantes compreender o mundo em que ele vive.

Ficaram de fora da BNCC algumas temáticas importantes para o ensino de Geografia, dentre elas o conceito de sociedade numa dimensão de classe e as contradições próprias dela mesma, "reforçando a concepção de um sujeito neoliberal absolutamente livre para realizar as decisões que poderão ser responsáveis pelo seu próprio sucesso e fracasso, em uma lógica de empresariamente de si”. (GIROTTO, 2018 p.27).

As redes de ensino deram seus passos na implantação da BNCC, começando pelas discussões, que também foram denominadas de contribuições, fato contraditório, para um documento aprovado e deliberado pelo MEC para implantação. No estado Pernambuco, toda a rede ensino foi convocada no dia 04/04/2018, como mostra o cartaz a seguir:

Figura 01: Cartaz fixado no corredor da escola Malaquias Mendes da Silva

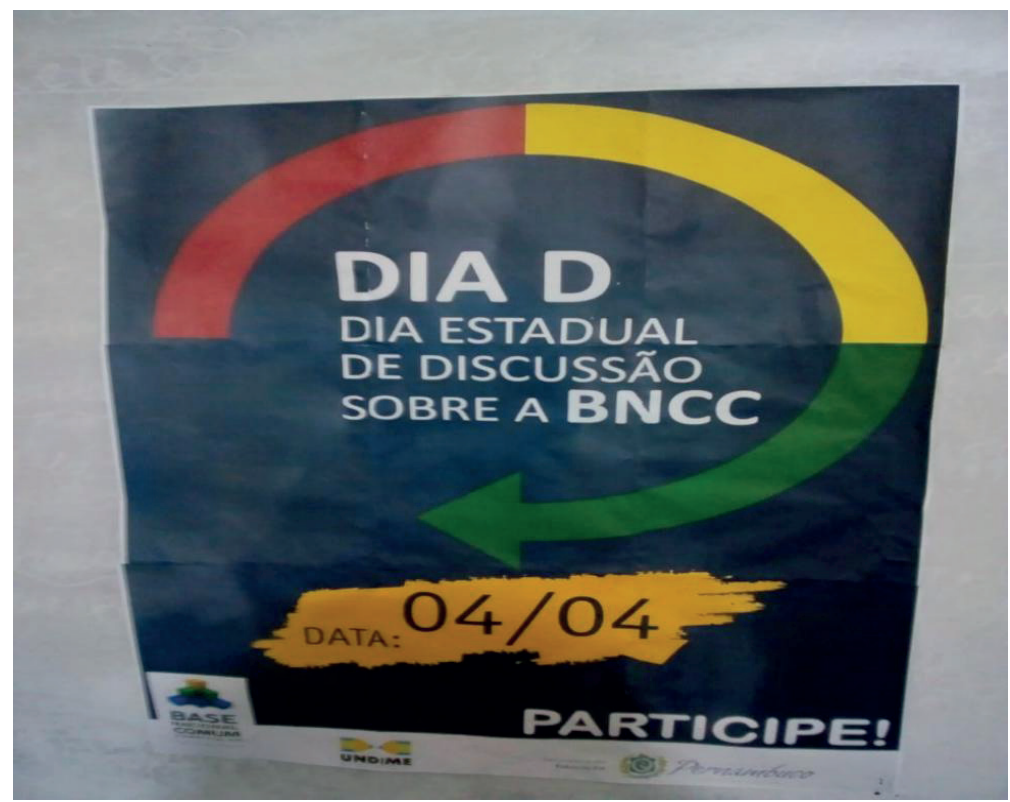

AMORIM, Alberto Filho Coelho de. 2018. 
As discussões realizadas nas escolas foram direcionadas por uma cartilha ${ }^{3}$ com o mesmo tema da figura acima. A mesma traz orientações sobre treinamento para desenvolvimento da BNCC nas redes de ensino e nas escolas, todavia alguns direcionamentos ferem, diretamente, os princípios da Educação do Campo, pois foi enfatizado nesse encontro que a BNCC diz o que o aluno deve aprender. Com isso, deixa entender que ela também diz o que o professor deve ensinar.

O dia D das discussões sobre a BNCC era para mostrar ao professor que, após a implantação desse documento nas escolas, as práticas de ensino e aprendizagem devem seguir os direcionamentos da Base Nacional Comum Curricular; portanto, é o documento obrigatório e não somente norteador como era nos PCNs.

Determinar que os professores discutissem mais 400 páginas da BNCC em algumas horas sem qualquer diálogo, apenas uma consulta para informar a concretização da BNCC, ilustra sua imposição. O dia "D" significa para o MEC, que as escolas estão discutindo como a Base irá ser operacionalizada, sem tecer discussões conjuntas sobre a Reforma do Ensino Médio e o trabalho docente com todas as mudanças. "No entanto, aquilo que pode parecer, em um primeiro momento, um fracasso da política educacional, precisa ser lida de forma ampliada, uma vez que, no discurso oficial, o fracasso vem acompanhado da intensificação da responsabilização docente". (GIROTTO, 2018 p.21)

Na contramão da BNCC, Educação do Campo é protagonista de um modelo de escola que conscientiza os alunos sobre as "contradições do âmbito da questão agrária, de projetos de agricultura ou de produção no campo, de matriz tecnológica, de organização do trabalho no campo e na cidade". (CALDART, 2012 p.263)

Nessa perspectiva, segundo CALDART, (2012), a Educação do Campo:

Combina luta pela educação com luta pela terra, pela reforma agrária, pelo direito ao trabalho, à cultura, à soberania alimentar, ao território. Por isso, sua relação de origem com os movimentos sociais de trabalhadores. Na lógica de seus sujeitos e suas relações, uma política de Educação do Campo nunca será somente de educação em si mesma e nem de educação escolar, embora se organize em torno dela (p.263).

Observa-se, nessa figura, que as atividades no dia D, as discussões foram apresentadas em torno das ações que serão desenvolvidas ainda no ano de 2018, dentre elas, a elaboração dos currículos escolares a partir da BNCC, os professores e diretores formados para trabalhar os conteúdos e adequação dos materiais didáticos para atender às exigências desse documentos.

As Avaliações Nacionais são pautadas pelo SAEB (Sistema Nacional de Avaliação da Educação Básica), e as da rede estadual de ensino de Pernambuco pelo SAEPE (Sistema de Avaliação da Educação Básica de Pernambuco). A rede Municipal de Ensino de Pe-

3 Atividades para o dia $\mathrm{D}$ referente as discussões da BNCC.

Disponível em:http://basenacionalcomum.mec.gov.br/wp-content/uploads/2018/03/3-apresentacao.pdf Acesso em: $29-06-2018$ 
trolina utiliza esses dois sistemas de avaliações como referências. Entretanto, elas servirão para justificar a necessidade de ter uma Base Nacional Comum Curricular, que promoverá a padronização do currículo nas escolas brasileiras, ao mesmo tempo, promovendo os resultados desejados nessas avaliações.

As avaliações mencionadas levaram as escolas a ter como principal foco os desempenhos dos alunos em Língua Portuguesa e Matemática, para alcançar anualmente as metas exigidas. No caso da Escola Estadual Malaquias Mendes da Silva, essa tem conseguido atingir os índices de forma crescente; no entanto, os alunos demonstram que têm o desejo de estudar, em sua escola, a realidade que eles vivem, como mostra o gráfico a seguir:

Gráfico 08: Interesses dos alunos em estudar a realidade camponesa

- Tem interesse $\quad$ Não tem interesse

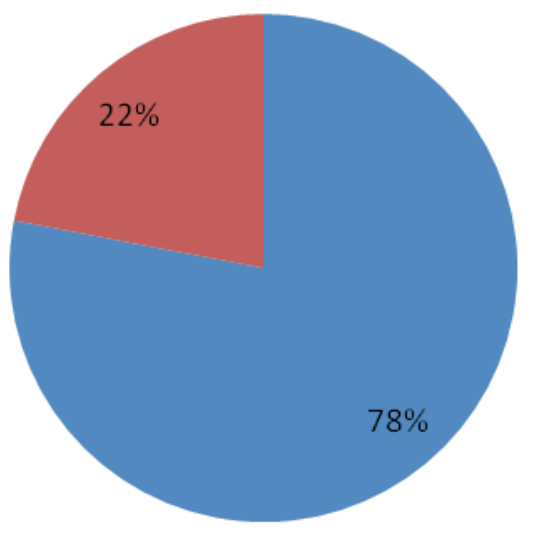

Fonte: Pesquisa de campo 2018. | Elaboração: AMORIM, Alberto Filho Coelho de. 2018.

A maioria dos alunos da escola Malaquias Mendes da Silva são filhos de agricultores e mantêm a produção agrícola familiar de acordo com suas perspectivas de educação. A BNCC não atende aos anseios deles, pois esse documento não oferece de forma real as garantias de trabalhar o cotidiano do ensino com a realidade camponesa e nem o mínimo de autonomia aos educadores.

Com a implantação da BNCC nas redes de ensino, as escolas estarão sujeitas a reproduzirem ideologias alienantes que promovam nos alunos e professores, a incapacidade de entender os conflitos numa sociedade de classe, e nem que posição deve ter nesse conflito; por isso, os camponeses continuarão lutando para que essas influências não se propaguem entre os que lutam por terra.

\section{CONSIDERAÇÕES FINAIS}

O argumento atual sobre a narrativa de que a BNCC foi construída democraticamente é embasada em quantificações e está estruturado no instrumento da consulta virtual, 
todavia, o número de contribuintes é muito pouco em relação ao contingente populacional e ao tamanho do Brasil, sem mencionar que, os envolvidos na construção da Base não relatam quais os tipos de contribuições foram essas.

A padronização dos currículos das escolas no campo e cidade, por meio da BNCC, com o objetivo de atender os índices das metas relacionadas às avaliações externas como o PISA, SAEB e SAEPE, nega ao camponês o direito de uma educação que tenha como princípio a construção do ensino com a participação dos sujeitos do campo.

A BNCC, ao contrário das propagandas na mídia e redes sociais, que constantemente relatam que a ela é a garantia de qualidade de ensino para todos, não traz nenhuma discussão sobre melhoria na infraestrutura das escolas ou a instalações de quadra esportivas cobertas e laboratórios de pesquisa cientifica, instrumentos importantes para qualidade de ensino, mas, negado para grande maioria das escolas.

A escola Malaquias Mendes da Silva atende demanda muito diferente das escolas que estão localizadas nas áreas irrigadas e na sede do Município de Petrolina. Os sujeitos que fazem parte dessa instituição de ensino têm particularidades que necessitam ser discutidas e trabalhadas na escola, principalmente no que se refere a produção agrícola familiar camponesa.

A inconsistência da BNCC no que se refere ao campo, particularmente, no Ensino Médio que não traz conteúdos, atribuindo competências para Ciências Humanas e Sociais Aplicadas e dentro delas os professores devem extrair conteúdos para Geografia, História, Sociologia e Filosofia, poderá perder questões conceituais da Geografia e das demais tão importante à leitura do mundo para os jovens na faixa etária requeridas para o Ensino Médio regular.

Nesse sentido, a Base Nacional Comum Curricular (BNCC) evidencia que o documento pouco reconhece a relação entre escola, espaço e sociedade, tomando as unidades escolares como indiferenciadas, alvo de políticas unitárias, contribuindo para a reprodução das desigualdades educacionais. Apontam-se, também, os possíveis impactos da Base sobre o processo de precarização do trabalho e da formação docente, com o avanço de uma lógica empresarial, que, centrada na produção de materiais didáticos, difunde a concepção de um professor como mero transmissor de conhecimentos.

Diante disso, a educação no/do campo ganha destaque por valorizar aqueles que têm especificidades diferentes já que a terra é a única garantia da existência. 


\section{REFERÊNCIAS}

ARROYO, Miguel G. Contribuições para a construção de um projeto de Educação do Campo / Mônica Castagna Molina e Sônia Meire Santos Azevedo de Jesus (organizadoras). Brasília, DF: Articulação Nacional "Por Uma Educação do Campo, 2004.

BRASIL, RESOLUÇÃO N 3, DE 2018. Atualiza as Diretrizes Curriculares Nacionais para o Ensino Médio. Diário Oficial da União, Brasília, DF, 22 nov. 2018, Seção 1, pp. 21-24.

BRASIL. Medida Provisória MPV 746/2016. Brasília, 22 set. 2016a. Disponível em: <http:// www. planalto.gov.br/ccivil_03/_ato2015-2018/2016/Mpv/mpv746.htm>. Acesso em: 21jan. 2017.

BRASIL. Base Nacional Comum Curricular: Ensino Médio. Brasília: MEC/Secretaria de Educação Básica, 2018.

BRASIL, Ministério da Educação. Base Nacional Comum Curricular - BNCC $3^{a}$ versão. Brasília, DF, 2017.

BRASIL. Ministério da Educação. Base Nacional Comum Curricular. 2a Edição Revista. 2016.

BRASIL, Ministério da Educação. Diretrizes Curriculares Nacionais para o Ensino Médio. Parecer CNE/CEB n 5/2011, aprovado em 4 de maio de 2011.

BRASIL, Diretrizes Operacionais para a Educação Básica nas Escolas do Campo. Resolução cne/ceb 1, de 3 de abril de 2002.

BRASIL. Secretaria de Educação Fundamental. Parâmetros curriculares nacionais: pluralidade cultural, orientação sexual. Brasília, DF: MEC/SEF, 1997.

BRASIL. Lei de Diretrizes e Bases da Educação Nacional. Lei $n^{\circ} 9.394$, de 20 de dezembro de 1996.

CALDART, Roseli Salete; PEREIRA, Isabel Brasil; ALENTEJANO, Paulo e FRIGOTTO, Gaudêncio. Dicionário da Educação do Campo. Rio de Janeiro, São Paulo: Escola Politécnica de Saúde Joaquim Venâncio, Expressão Popular, 2012.

CALDAR, Roseli Salete. Educação do campo. In: Dicionário da Educação do Campo. / Organizado por Roseli Salete Caldart, Isabel Brasil Pereira, Paulo Alentejano e Gaudêncio Frigotto. Rio de Janeiro, São Paulo: Escola Politécnica de Saúde Joaquim Venâncio, Expressão Popular, 2012.

CALDEIRA, Anna Maria Salgueir; ZAIDAN, Samira. Práxis Pedagógica: Um Desafio Cotidiano. Paidéia, Belo Horizonte, v. 10, n. 14, p. 15-32, 2013. Disponível em: <http://www.fumec.br/revistas/ paideia/article/view/2374/1430>. Acesso em: 01 jun. 2018.

CARDOSO, Fernando Henrique. Mãos à Obra Brasil: Proposta de Governo. Brasília: [s.n.], 1994.

CARVALHO, Agenor Manoel de. Evidência olhares e pesquisa em saberes educacionais/ Centro Universitário do Planalto de Araxá, Instituto Superior de Educação. vol.6, 2010. 
CURY, Carlos Roberto Jamil. A educação superior na nova Lei de Diretrizes e Bases da Educação Nacional: uma nova reforma? In: CATANI, Afrânio Mendes (org.). Novas perspectivas nas políticas de educação superior na América Latina no limiar do século XXI. Campinas: Autores Associados, 2008. p. 75-81.

FERRARO, Alceu Ravanello; RIBEIRO, Marlene. Trabalho Educação Lazer: construindo políticas públicas. Pelotas: Educat, 2001.

FONSECA, Marília. A educação brasileira sob o manto ideológico e financeiro do Banco Mundial. In: MARTINS, Mônica Dias; GALLI, Rosemary (org.). Multilateralismo e reações sul-americanas. Fortaleza: EdUECE, 2011. p. 227-254.

FREITAS, Luiz Carlos. Base Nacional Comum: personagens. Disponível em: <http://avaliacaoeducacional.com/2014/07/06/base-nacional-comum-personagens/> Acesso em 10 de Abril. de 2018.

GIROTTO, Eduardo Donizeti. Entre o abstracionismo pedagógico e os territórios de luta: a base nacional comum curricular e a defesa da escola pública. Horizontes, v. 36, n. 1, p. 16-30, jan./abr. 2018.

GRAMSCI, Antônio. Quaderni Del Cárcere. 2ª ed.Turim, Giulio Einauldi,1977.

GRAMSCI, Antônio. Maquiavel, a política e o Estado moderno. Tradução de C. N. Coutinho. 3. ed. Rio de Janeiro: Civilização Brasileira, 1978.

HARVEY, David. O enigma do capital e as crises do capitalismo. São Paulo: Boitempo, 2011.

HIDALGO, A. M. De "educação para responsabilização individual” para "educação e consciência de classe". In: ORSO, J. P.; GONÇALVES, S. R.; MATTOS, V. M. (Orgs.). Educação e lutas de classes. São Paulo: Expressão Popular, 2008, p. 125-138.

LIMA, Ricardo. Mercado de Trabalho: 0 capital humano e a teoria da segmentação. Pesquisa Plano Econômico, Rio de Janeiro, 1980, p. 217-272.

MACEDO. Elizabeth. Base nacional curricular comum: novas formas de sociabilidade produzindo sentidos para educação. Revista e-Curriculum, São Paulo, v. 12, n. 03 p.1530 - 1555 out./dez. 2014.

MÉSZÁROS, István. A crise estrutural do capital. Trad. Francisco Raul Cronejo. São Paulo. $2^{\circ}$ edição; Boitempo, 2011

MÉSZÁROS, István. A educação para além do capital. Isa Tavares (Trad.). 2. Ed. São Paulo: Boitempo, 2008.

MOREIRA, Antônio Flavio. (Org.) (2004). Currículo: questões atuais. 10.ed. Campinas: Papirus, 1997.

NETTO, José Paulo. Entrevista com José Paulo Netto.Trabalho, Educação e Saúde, Rio de Janeiro, v. 9 n. 2, p. 333-340, jul. /out.2011. 
OLIVEIRA, Adriano Rodrigo. Geografia e Cartografia Escolar: o que sabem e como ensinam professoras das séries iniciais do Ensino Fundamental. In: Revista Educação e Pesquisa, vol. 34, $n^{\circ}$. 3 , septiembre-deciembre, pp. 481-494. USP, 2008.

PRONKO, Marcela. O Banco Mundial no campo internacional da educação. In: A demolição de direitos: um exame das políticas do Banco Mundial para a educação e a saúde (1980-2013) / Organização de João Márcio Mendes Pereira e Marcela Pronko. - Rio de Janeiro: Escola Politécnica de Saúde Joaquim Venâncio, 2014.

SOUSA, Jorge Luís Umbelino de. Currículos e Projetos de Formação: Base Nacional Comum Curricular e seus desejos de performance. Espaço do Currículo, João Pessoa, v. 8, n. 3, p. 323-334, set/dez. 2015.

SOUZA, Paulo Renato. Education and Development in Brazil, 1995-2000. Cepal Review, n. 73, p. 65-80, Apr. 2001.

WORLD BANK. Education Sector Strategy. Washington, D.C.: The World Bank Group World. Human Development Network, 1999.

TERRA, Lígia; COELHO, Marcos de Amorim. Geografia Geral e do Brasil: o espaço natural e socioeconômico. 1. ed. v. 1. São Paulo: Moderna, 2005. 